\title{
Antimalarial Activities of Hydromethanolic Crude Extract and Chloroform Fraction of Gardenia ternifolia Leaves in Plasmodium berghei Infected Mice
}

\author{
Tezera Jemere Aragaw ${ }^{D},{ }^{1}$ Dessie Tegegne Afework, ${ }^{2}$ and Kefyalew Ayalew Getahun ${ }^{1}$ \\ ${ }^{1}$ Department of Pharmacology, College of Medicine and Health Sciences, University of Gondar, Gondar, Ethiopia \\ ${ }^{2}$ Department of Medical Laboratory, College of Health Sciences, Debre Tabor University, Debre Tabor, Ethiopia \\ Correspondence should be addressed to Tezera Jemere Aragaw; tezeraadis1982@gmail.com
}

Received 31 October 2020; Revised 9 December 2020; Accepted 13 December 2020; Published 29 December 2020

Academic Editor: Daniela Rigano

Copyright (C) 2020 Tezera Jemere Aragaw et al. This is an open access article distributed under the Creative Commons Attribution License, which permits unrestricted use, distribution, and reproduction in any medium, provided the original work is properly cited.

\begin{abstract}
Background. Gardenia ternifolia is utilized in traditional medicine of Ethiopia for malaria treatment and possessing in vitro antimalarial activity. However, no in vivo study was conducted to substantiate the claim. The aim of this study was to judge the antimalarial activity of Gardenia ternifolia extract in vivo in Plasmodium berghei-infected mice. Methods. Plasmodium berghei was inoculated to healthy mice, and hydromethanolic crude extract and chloroform fraction of G. ternifolia leaves at $100 \mathrm{mg} / \mathrm{kg} / \mathrm{day}$, $200 \mathrm{mg} / \mathrm{kg} / \mathrm{day}$, and $400 \mathrm{mg} / \mathrm{kg} /$ day were administered. Percent parasitemia inhibition, percent change in bodyweight, hemoglobin level, and mean survival time were determined. Data were analyzed using one-way ANOVA followed by post hoc Tukey HSD test with IBM SPSS software version 20.0 statistical package and $P<0.05$ considered as statistically significant. Results. The chemosuppressive test of hydromethanolic crude extract at $100 \mathrm{mg} / \mathrm{kg} / \mathrm{day}, 200 \mathrm{mg} / \mathrm{kg} / \mathrm{day}$, and $400 \mathrm{mg} / \mathrm{kg} / \mathrm{day}$ ranged from $27.09 \%$ to $67.72 \%$, and chloroform fraction had $35.21 \%-78.19 \%$ parasitemia suppression, respectively. For curative test on day 5 , hydromethanolic crude extract at $100 \mathrm{mg} / \mathrm{kg} / \mathrm{day}, 200 \mathrm{mg} / \mathrm{kg} / \mathrm{day}$, and $400 \mathrm{mg} / \mathrm{kg} / \mathrm{day}$ ranged from $25.58 \%$ to $48.76 \%$, chloroform fraction at $100 \mathrm{mg} / \mathrm{kg} / \mathrm{day}, 200 \mathrm{mg} / \mathrm{kg} /$ day, and $400 \mathrm{mg} / \mathrm{kg} /$ day and chloroquine base at $10 \mathrm{mg} / \mathrm{kg}$ showed $46.36 \%-74.42 \%$ and $92.87 \%$ percent parasitemia inhibition, respectively, and also the results to both tests were highly significant $(P<0.001)$ compared to the negative control. Maximum effects on chemosuppressive, curative, prevention of weight loss, and reduction in hemoglobin were observed at higher doses of the hydromethanolic crude extract and chloroform fraction. Conclusion. From this study, hydromethanolic crude extract and chloroform fraction of $G$. ternifolia leaves have shown promising antimalarial activity. The findings support the traditional claim of $G$. ternifolia leaves for malaria treatment; however, species variation could also limit such a straightforward extrapolation of the findings of this study in humans.
\end{abstract}

\section{Background}

Globally, in 2019, there were an estimated 229 million malaria cases of which an estimated $94 \%$ (215 million) cases occurred in Africa [1]. Resistance of Plasmodium falciparum to the cheap and safe chloroquine (CQ) and to sulfadoxinepyrimethamine (SP) caused a major drawback in effective malaria control in sub-Saharan Africa [2, 3]. Gardenia ternifolia is an evergreen small tree that grows to six meters tall [4]. The intertwined branches have short twigs which are very hard and thorny [5]. Ethnomedical information indicates that G. ternifolia (Rubiaceae) has been utilized by traditional healers to palliate malaria and its related fevers $[6,7]$. Fresh leaves and edible fruit extracts that are accustomed in managing hemorrhoid lesions showed an antidiabetic activity [8]. The macerated root extract is employed as a laxative and vermifuge for the treatment of stomach aches and kwashiorkor [9].

The crude acetone extract of $G$. ternifolia showed $\mathrm{IC}_{50}$ values of 1.06 and $0.94 \mu \mathrm{g} / \mathrm{ml}$ against chloroquine-resistant Indochina (W2) and chloroquine sensitive to Sierra-Leone (D6) strains of Plasmodium falciparum [10]. 


\section{Rationale of the Study}

Gardenia ternifolia leaves in vitro and ethnobotanical studies showed antimalarial activity; no report is offered in the literature whether the leaves possess in vivo activity. This study was therefore planned to evaluate the efficacy as well as acute oral toxicity of $G$. ternifolia leaves used as malaria treatment in the Ethiopian folk medicine.

\section{Materials and Methods}

3.1. Plant Material. Fresh leaves of G. ternifolia were collected on October 13, 2016, from Gondar Zuria district, Degola Chinchaye kebele, about $45 \mathrm{~km}$ south of the town, northwest Ethiopia. The collected material was wrapped and covered with plastic sheets during transportation. The specimen of the plant was authenticated as Gardenia ternifolia by a botanist (Getnet Chekole), in the Department of Biology, the University of Gondar, and was deposited in the herbarium with a voucher specimen (No. KA1784) for future reference.

3.2. Preparations of Hydromethanolic Crude Extract. The leaves of $G$. ternifolia were dried under shade, grounded to a course powder using hand compression, and stored in glass jars at room temperature until extraction. $400 \mathrm{~g}$ of G. ternifolia leaves powder was macerated in $2400 \mathrm{ml}$ in $80 \%$ hydromethanol and shook frequently. After 72 hours of maceration, extraction was performed using thick layers of 40 mesh gauze and filtered with Whatman paper No. 1 twice, and the $2^{\text {nd }}$ extraction was repeated after 72 hours of after maceration; the $3^{\text {rd }}$ extraction was repeated 72 hours later (in a complete of nine days). The extracts were combined and concentrated in a dry oven at $40^{\circ} \mathrm{C}$ [11].

3.3. Preparation of Chloroform Fraction. The hydromethanolic crude extract was subjected to fractionation using solvents with differing polarity (chloroform and water). $40 \mathrm{~g}$ of hydromethanolic crude extract powder was suspended in a separatory funnel using $400 \mathrm{ml}$ water and similar volume of chloroform was added and shaken to mix and left for 12 hours. The chloroform portion was powered in a clean beaker and concentrated in a dry oven at $40^{\circ} \mathrm{C}$ and stored in a refrigerator at $4^{\circ} \mathrm{C}$ until use $[11,12]$.

3.4. Phytochemical Screening. The qualitative phytochemical screening tests were performed on $80 \%$ hydromethanolic crude extract of $G$. ternifolia leaves using standard chemicals and procedures which were utilized in previous researches [13-21].

3.5. Animals and Parasite. Swiss albino mice, weighing within 20-28 g, 6-8 weeks old, and either sex, were purchased from the Ethiopian Public Health Institute (EPHI), Addis Ababa. Mice were kept in cages and housed in a standard animal house under a natural 12/12 h light-dark cycle at room temperature with free access to food and water.
Before the experiment, they were acclimatized to the test environment for five days. The care and handling were consistent with the international guidelines for the employment and maintenance of experimental animals $[22,23]$.

Chloroquine-sensitive malaria, $P$. berghei, was obtained from EPHI in the Traditional Medicine Research Department, Addis Ababa, and transported by infecting the donor mice and maintaining the parasite until the actual procedure of the study.

3.6. Acute Toxicity Test. Five female mice were kept for five days before dosing to acclimatize. One mouse was randomly taken to work out preliminary toxicity observation on free access to water but fasted for four hours and weighed and hydromethanolic crude extract of $G$. ternifolia leaves at $2000 \mathrm{mg} / \mathrm{kg}$ was administered by the oral route. Strict observation was carried out for half an hour and periodically for the first 24 hours, for consecutive fourteen days. Observation was majorly focused on physical and behavioral changes of the mouse. But preliminary toxicity observation of the mouse did not show any sign of toxicity for four days. The remaining 4 mice were dosed by similar doses and followed for 14 days [21, 24].

3.7. Pharmacologic Screening (4-Day Suppressive Test). Donor P. berghei infected mice (parasitemia of roughly $30 \%$ ) were sacrificed by decapitation; then, blood was collected through cardiac puncture with a sterile disposable needle and syringe. The blood was diluted with sterile sodium chloride $0.9 \%$ in water in such a way that $0.2 \mathrm{ml}$ of blood contained about $10^{7}$ infected red blood cells (RBCs) and mice were infected by $0.2 \mathrm{ml}$ blood suspension intraperitoneally expected to produce steadily rising consistent infection of the specified intensity in mice [23]. Then, mice were randomly divided into eight groups of six each, weighed, and maintained on a standard diet. The doses of hydromethanolic crude extract and chloroform fraction were adjusted from the safest dose of acute toxicity study and were $5 \%, 10 \%$, and $20 \%$ from lower to higher doses, respectively. Three different doses got to the mice of hydromethanolic crude extract and chloroform fraction once daily for 4 days. The seventh group was treated with chloroquine base at $10 \mathrm{mg} / \mathrm{kg} /$ day (positive control), and the eighth group received $10 \mathrm{ml} / \mathrm{kg} /$ day of solvent which contained $3 \mathrm{ml}$ of $96 \%$ ethanol $+7 \mathrm{ml}$ of Tween $80+90 \mathrm{ml}$ of water (negative control) $[25,26]$ administered orally using oral gavage, starting from 3 hours of parasite inoculation.

3.8. Rane's (Curative) Test. An evaluation of the curative potential of hydromethanolic crude extract and chloroform fraction of $G$. ternifolia leaves was distributed consistent with the strategy described by curative methods [24]. On Day 0 , standard inocula of about $10^{7}$ infected erythrocytes were inoculated in mice intraperitoneally and randomly divided into their respective groups, weighed, and maintained on a pellet diet. Seventy-two hours later, they were 
dosed with hydromethanolic crude extract at $100 \mathrm{mg} / \mathrm{kg} /$ day, $200 \mathrm{mg} / \mathrm{kg} / \mathrm{day}$, and $400 \mathrm{mg} / \mathrm{kg} /$ day and chloroform fraction at $100 \mathrm{mg} / \mathrm{kg} /$ day, $200 \mathrm{mg} / \mathrm{kg} /$ day, and $400 \mathrm{mg} / \mathrm{kg} /$ day, chloroquine base at $10 \mathrm{mg} / \mathrm{kg} /$ day and solvent $10 \mathrm{ml} / \mathrm{kg} /$ day, which was prepared from $3 \mathrm{ml}$ of $96 \%$ ethanol $+7 \mathrm{ml}$ of Tween $80+90 \mathrm{ml}$ of water once daily for five days. A Giemsa-stained thin blood film was prepared from the tail of each mouse daily for five days (days 3, 4, 5, 6, and 7) to determine the parasitemia level. The mean survival time for each group was resolute arithmetically by calculating the mean survival time (days) of mice starting from the date of infection over a period of 30 days (D0-D29) [26].

\section{Determination of Parasitemia}

On day 4 (96 hours), after infection, a drop of blood was collected from the mice by the vein section of the tail and transferred onto the edge of a microscopic slide and drawn evenly across the second slide to create a thin blood film and allowed to dry at room temperature, fixed with methanol, and stained with $10 \%$ Giemsa stain for quarter an hour. Slides were viewed using light microscopy with oil immersion (1000 x magnification). Percentage parasitemia was determined by counting the number of parasitized red blood cells (PRBCs) and non-infected red blood cell in random fields of the microscope. Five fields were counted and the parasitemia was calculated as the percentage of the total RBCs containing PRBCs [27].

4.1. Percent Parasitemia. Percent parasitemia was calculated according to the following formula [27]:

$$
\% \text { parastemia }=\frac{\text { total number of } \mathrm{PRBC}}{\text { total number of } \mathrm{RBC}} \times 100,
$$

where PRBC is parasitized red blood cells.

4.2. Red Blood Cells (RBC). Average percentage of parasitemia suppression was calculated as follows:

$$
\text { average } \% \text { of parastemia suppression }=\frac{\text { Av. } \% \text { of parasitemia in control }- \text { Av. } \% \text { of parasitemia in test }}{\text { Av. } \% \text { of parasitemia in control }} \times 100
$$

where Av. = average.

4.3. Determination of Bodyweight. The bodyweights of the mice were measured to observe whether the test extract of
G. ternifolia leaves prevented bodyweight loss. The weights were taken on day 0 (after an infection was initiated) and day $4[25,26]$ :

$$
\begin{gathered}
\text { body weight change }=\text { body weight day } 4-\text { body weight day } 0, \\
\text { percent body weight change }=\frac{\text { body weight day } 4-\text { body weight day } 0}{\text { body weight day } 4} \times 100 \text {. }
\end{gathered}
$$

4.4. Determination of Hemoglobin Level. The hemoglobin level of the mice was measured to evaluate the effectiveness of hydromethanolic crude extract and chloroform fraction $G$. ternifolia leaves prevented anemia. Hemoglobin was evaluated by using hemoglobin machine and hemoglobin cuvette. From vein section of tail of mice, blood sample was collected by a trained medical laboratory technologist with optimum pressure applied on the tail and filled microcuvette (Hb 301) approximately $10 \mu \mathrm{l}$. Before inserting the microcuvette into the machine, excess blood was removed. The machine was run; hemoglobin level in $\mathrm{g} / \mathrm{dl}$ was displayed automatically and recorded. Finally, mean hemoglobin level was determined [28]:

$$
\text { mean hemoglobin }=\frac{\text { sum of hemoglobin for all mice in a group }(\text { in } \mathrm{g} / \mathrm{dl})}{\text { total number of mice in that group }} .
$$

4.5. Determination of Mean Survival Time. Any death was recorded within 28 days of the study period to evaluate the hydromethanolic crude extract and chloroform fraction effect for improvement in survival days. The mice were maintained with free access to food and water $[25,26]$ : 
mean survival times $=\frac{\text { sum of survival times for all mice a group (in days) }}{\text { total number of mice in this group }}$.

4.6. Data Analysis. The results of the study were expressed as the mean \pm standard error of the mean $(M \pm$ SEM). Comparison of parasitemia and statistical significance resolved by one-way ANOVA descriptive statistics. Post hoc tests for multiple comparisons of Tukey HSD and paired $t$-test were employed to test significance for the difference between initial and final results within the identical and in between groups using IBM SPSS for window (Version 20.0) statistical package. All data were analyzed at a $95 \%$ confidence interval and $P<0.05$ was considered statistically significant.

\section{Results}

The yield and percent yield of hydromethanolic crude extract were found to be $42.6 \mathrm{~g}(10.65 \%)$ and stored in a refrigerator at $4^{\circ} \mathrm{C}$ until use.

5.1. Phytochemical Screening. The preliminary phytochemical screening of $80 \%$ hydromethanolic crude extract of G. ternifolia leaves for the probable presence of different secondary metabolites is summarized in Table 1.

5.2. Acute Toxicity Study. The acute toxicity study indicated that the hydromethanolic crude extract of $G$. ternifolia leaves did not cause mortality of mice within 24 hours up to $2000 \mathrm{mg} / \mathrm{kg}$ bodyweight. Gross physical and behavioral observation of the experimental mice also revealed no visible signs of acute toxicity like lacrimation, hair erection, and reduction in their motor and feeding activities. They were physically active for 14 days after plant extract administration.

5.3. Antimalarial Suppressive Test. Antimalarial suppressive test of hydromethanolic crude extract and chloroform fraction of $G$. ternifolia leaves in $P$. berghei infected mice resulted in reduced parasite load as compared to their respective negative control group. Positive control groups treated with chloroquine base $10 \mathrm{mg} / \mathrm{kg} /$ day cleared the parasite on day 4 under identical conditions. Hydromethanolic crude extract at $100 \mathrm{mg} / \mathrm{kg} /$ day, $200 \mathrm{mg} / \mathrm{kg} /$ day, and $400 \mathrm{mg} / \mathrm{kg} /$ day showed $27.09,44.72$, and $67.72 \%$ parasitemia inhibition, respectively, and chloroform fraction at $100 \mathrm{mg} / \mathrm{kg} /$ day, $200 \mathrm{mg} / \mathrm{kg} /$ day, and $400 \mathrm{mg} / \mathrm{kg} /$ day showed $35.21,63.95$, and $78.19 \%$ parasitemia inhibition, respectively, and the results were highly significant $(P<0.001)$ compared to the negative control group at day 4 (see Table 2 ).

Plasmodium berghei infected mice treated with hydromethanolic crude extract of G. ternifolia leaves at $100 \mathrm{mg} / \mathrm{kg} /$ day $-15.22 \pm 1.88 \%(P=0.1000)$ change in bodyweight, $200 \mathrm{mg} / \mathrm{kg} /$ day $-7.85 \pm 1.65 \%(P=0.118)$ change in bodyweight, $400 \mathrm{mg} / \mathrm{kg} / \mathrm{day}-2.90 \pm 1.82 \%(P<0.001)$ change in bodyweight and chloroform fraction at $100 \mathrm{mg} / \mathrm{kg} / \mathrm{day}$ $-9.14 \pm 0.88 \%(P=0.324)$ change in bodyweight, $200 \mathrm{mg} /$ $\mathrm{kg} /$ day $-5.95 \pm 0.72 \%(P=0.017)$ change in bodyweight, $400 \mathrm{mg} / \mathrm{kg} /$ day $-2.85 \pm 1.37 \%(P<0.001)$ of bodyweight and chloroquine base at $10 \mathrm{mg} / \mathrm{kg} /$ day gain $3.87 \%(P<0.001)$ of bodyweight and mice treated with solvent $10 \mathrm{ml} / \mathrm{kg} /$ day loss $14.68 \%$ of bodyweight (see Figure 1).

The hydromethanolic crude extract of $G$. ternifolia leaves showed average hemoglobin levels at $100 \mathrm{mg} / \mathrm{kg} / \mathrm{day}$ $7.57 \pm 0.24 \mathrm{~g} / \mathrm{dl}(P=0.668), 200 \mathrm{mg} / \mathrm{kg} /$ day $9.87 \pm 0.40 \mathrm{~g} / \mathrm{dl}$ $(P<0.001), \quad 400 \mathrm{mg} / \mathrm{kg} /$ day $12.95 \pm 0.54 \mathrm{~g} / \mathrm{dl} \quad(P<0.001)$, chloroform fraction at $100 \mathrm{mg} / \mathrm{kg} /$ day $8.98 \pm 0.32 \mathrm{~g} / \mathrm{dl}$ $(P<0.001), \quad 200 \mathrm{mg} / \mathrm{kg} / \mathrm{day} \quad 11.82 \pm 0.13 \mathrm{~g} / \mathrm{dl} \quad(P<0.001)$, $400 \mathrm{mg} / \mathrm{kg} /$ day $13.97 \pm 0.40 \mathrm{~g} / \mathrm{dl} \quad(P<0.001)$, chloroquine base at $10 \mathrm{mg} / \mathrm{kg} /$ day $14.15 \pm 0.32 \mathrm{~g} / \mathrm{dl}(P<0.001)$ and noninfected mice $14.37 \pm 0.24 \mathrm{~g} / \mathrm{dl}(P<0.001)$ compared to the negative control $(6.55 \pm 0.68 \mathrm{~g} / \mathrm{dl})$ (see Figure 2$)$.

Hydromethanolic crude extract of $G$. ternifolia leaves at $100 \mathrm{mg} / \mathrm{kg} /$ day, $200 \mathrm{mg} / \mathrm{kg} /$ day, and $400 \mathrm{mg} / \mathrm{kg} /$ day showed $6.5 \pm 0.22(P=1.000), \quad 7.330 .33 \quad(P=0.999), \quad 11.17 \pm 0.60$ $(P=0.440)$, chloroform fraction at $100 \mathrm{mg} / \mathrm{kg} / \mathrm{day}, 200 \mathrm{mg} /$ $\mathrm{kg} /$ day, $400 \mathrm{mg} / \mathrm{kg} /$ day $7.33 \pm 0.33(P=0.999), 10.17 \pm 0.70$ $(P=0.689), 14.17 \pm 0.31(P=0.042)$ and chloroquine base at $10 \mathrm{mg} / \mathrm{kg} /$ day showed $24.00 \pm 1.83(P<0.001)$ days of mean survival time in four-day suppressive test, respectively, and chloroform fraction at $400 \mathrm{mg} / \mathrm{kg} /$ day showed significant difference $(P<0.05)$ in survival days compared to negative controls and infected mice treated with chloroquine base at $10 \mathrm{mg} / \mathrm{kg} /$ day showed highly significant $(P<0.001)$ in survival days compared to negative controls $(5.50 \pm 0.43)$ (see Figure 3).

5.4. Antimalarial Curative Test. Antimalarial curative test of hydromethanolic crude extract of $G$. ternifolia leaves at $100 \mathrm{mg} / \mathrm{kg} /$ day, $200 \mathrm{mg} / \mathrm{kg} /$ day, $400 \mathrm{mg} / \mathrm{kg} /$ day and chloroform fraction of $G$. ternifolia leaves at $100 \mathrm{mg} / \mathrm{kg} / \mathrm{day}$, $200 \mathrm{mg} / \mathrm{kg} / \mathrm{day}, 400 \mathrm{mg} / \mathrm{kg} /$ day and chloroquine base $10 \mathrm{mg} /$ $\mathrm{kg} /$ day in $P$. berghei infected mice at day 5 showed 25.58, $36.98,48.76,46.36,62.87,74.42$, and 92.87 percent parasitemia inhibition, respectively (see Table 3 ).

Hydromethanolic crude extract of $G$. ternifolia leaves at $100 \mathrm{mg} / \mathrm{kg} /$ day, $200 \mathrm{mg} / \mathrm{kg} /$ day, $400 \mathrm{mg} / \mathrm{kg} /$ day and chloroform fraction of $G$. ternifolia leaves at $100 \mathrm{mg} / \mathrm{kg} /$ day, $200 \mathrm{mg} / \mathrm{kg} / \mathrm{day}, 400 \mathrm{mg} / \mathrm{kg} / \mathrm{day}$ and chloroquine base at $10 \mathrm{mg} / \mathrm{kg} /$ day showed $7.00 \pm 0.26$ days $(p=0.037)$, $8.33 \pm 0.33$ days, $10.33 \pm 0.33$ days, $9.00 \pm 0.26$ days, $11.83 \pm 0.48$ days, $14.50 \pm 0.62$ days and $30.00 \pm 0.00$ days of mean survival time in curative test, respectively, and were highly significant differences $(p<0.001)$ compared to negative control which was $5.33 \pm 0.21$ days (see Figure 4 ).

\section{Discussion}

Currently, malaria management causes an unlimited threat due to resistance of plasmodium species to available drugs $[2,3]$. There is a requirement to possess a replacement and 
Table 1: Phytoconstituents of hydromethanolic crude extract of G. ternifolia leaves.

\begin{tabular}{|c|c|c|c|}
\hline Phytochemical & Type of test & Appearance when positive & Result \\
\hline Alkaloids & Wagner's and Mayer's tests & $\begin{array}{l}\text { Reddish brown and white creamy } \\
\text { ppt }\end{array}$ & + \\
\hline Anthraquinones & (Borntrager's test) chloroform $+\mathrm{NaOH}$ & Red colour & + \\
\hline $\begin{array}{l}\text { cardiac } \\
\text { glycosides }\end{array}$ & $\begin{array}{c}\text { (Keller-Killani test) glacial acetic acid }+ \text { ferric chloride }+ \text { concentrated } \\
\text { sulfuric acid }\end{array}$ & A brown ring & - \\
\hline Flavonoids & Alkaline reagent test & Colourless & + \\
\hline Phenols & Ferric chloride & Bluish black & + \\
\hline Resins & Ethanol + distilled water & Formation of a precipitate & - \\
\hline Saponins & Foam test & Foam & + \\
\hline Sterols & (Liebermann-Burchard test) chloroform + acetic acid + sulphuric acid & Blue green ring & + \\
\hline Tannins & Ferric chloride & $\begin{array}{l}\text { A brownish green or blue black } \\
\text { coloration }\end{array}$ & + \\
\hline Terpenoids & (Salkowski test) sulphuric acid + chloroform & Reddish brown & + \\
\hline
\end{tabular}

$(+)$ indicates presence; $(-)$ indicates absence; ppt.: precipitate.

TABLE 2: Mean percent parasitemia and mean percent parasitemia inhibition of $P$. berghei-infected mice treated with hydromethanolic crude extract and chloroform fraction of Gardenia ternifolia leaves in the 4-day suppressive test.

\begin{tabular}{lcc}
\hline Extract & Mean percent parasitemia & Mean percent parasitemia inhibition \\
\hline CON $10 \mathrm{ml} / \mathrm{kg}$ & $43.00 \pm 1.58$ & 0.00 \\
CM $100 \mathrm{mg} / \mathrm{kg}$ & $31.35 \pm 0.57$ acde $(3)$ & 27.09 \\
CM $200 \mathrm{mg} / \mathrm{kg}$ & $23.77 \pm 0.52 \mathrm{abde}(3)$ & 44.72 \\
CM $400 \mathrm{mg} / \mathrm{kg}$ & $13.88 \pm 0.35 \mathrm{abce}(3)$ & 67.72 \\
CF $100 \mathrm{mg} / \mathrm{kg}$ & $27.86 \pm 0.67$ acde (3) & 35.21 \\
CF $200 \mathrm{mg} / \mathrm{kg}$ & $15.50 \pm 0.41 \mathrm{abde}(3)$ & 63.95 \\
CF $400 \mathrm{mg} / \mathrm{kg}$ & $9.38 \pm 0.25 \mathrm{abce}(3)$ & 78.19 \\
CQ $10 \mathrm{mg} / \mathrm{kg}$ & $0.00 \pm 0.00 \mathrm{abcd}(3)$ & 100 \\
\hline
\end{tabular}

Data are expressed as mean \pm SEM; $(n=6, C O N=$ control, $C M$, crude hydromethanolic extract, $C F=$ chloroform fraction of Gardenia ternifolia, and $\mathrm{CQ}=$ chloroquine). a, compared to negative control; b, compared to $100 \mathrm{mg} / \mathrm{kg}$; c, compared to $200 \mathrm{mg} / \mathrm{kg}$; d, compared to $400 \mathrm{mg} / \mathrm{kg}$; e, CQ10 mg/kg: $3 P<0.001$.

effective agent. Therefore, we assessed antimalarial activity of hydromethanolic crude extract and chloroform fraction of G. ternifolia leaves in $P$. berghei infected mice. Ethnomedical information indicates that G. ternifolia (Rubiaceae) has been employed by traditional healers to palliate malaria and its related fevers $[6,7]$. It is also used to manage hemorrhoids lesions, diabetes, constipation, stomachache, and vermifuge activity [9], from the promising results of the in vitro cell culture of chloroquine-resistant Indochina (W2) and chloroquine sensitive to Sierra-Leone (D6) strains of Plasmodium falciparum [9]. The in vivo activities of hydromethanolic crude extract and chloroform fraction of G. ternifolia leaves were evaluated. The hydromethanolic crude extract yield of G. ternifolia leaves was $10.65 \% \mathrm{w} / \mathrm{w}$ which is not up to the G. ternifolia root bark (19\% w/w) [12]. The medicinal plant (G. ternifolia) contains considerable secondary bioactive constituents like alkaloids, anthraquinones, flavonoids, phenols, saponins, sterols, tannins, and terpenoids [14-21]. The antimalarial effects of both hydromethanolic crude extract and chloroform fraction of G. ternifolia leaves have higher mean percent parasitemia inhibition, reduction in weight, prevention of anemia, and a rise in mean survival time in days in a dose-dependent manner. Alkaloids are attributed to their ability to intercalate with DNA and terminate division of cells [14].
Flavonoids have an ability to complex with extracellular and soluble proteins and to complex with organisms' cell components. More lipophilic flavonoids may disrupt microbial membranes, inactivate toxins, and inhibit isolated enzymes and complexing activities $[10,16]$. Phenolic toxicity produced by phenolic compounds to microorganisms includes enzyme inhibition by the oxidized compounds, possibly through reaction with sulfhydryl groups or through more nonspecific interactions with the proteins [29]. Tannins stimulate phagocytic cells, host-mediated tumor activity complexation with proteins through so-called nonspecific forces like hydrogen bonding and hydrophobic effects, further by attractive force formation [30]. The terpenes' mechanism of action is not fully understood but is purported to involve membrane disruption by the lipophilic compounds [10, 16]. Hydroethanolic crude extract of G. ternifolia leaves did not cause any overt morbidity and mortality in the experimental mice at $2,000 \mathrm{mg} / \mathrm{kg}$ oral administration. This showed that a median lethal dose of $50 \%\left(\mathrm{LD}_{50}\right)$ is larger than $2,000 \mathrm{mg} / \mathrm{kg}$, which attests that plant products are frequently considered to be safe and have fewer adverse effects than synthetic ones [22, 23]. However, species variations would limit such a clear-cut extrapolation of the findings of this study to humans. The in vivo antiplasmodial activities of hydromethanolic crude extract and 

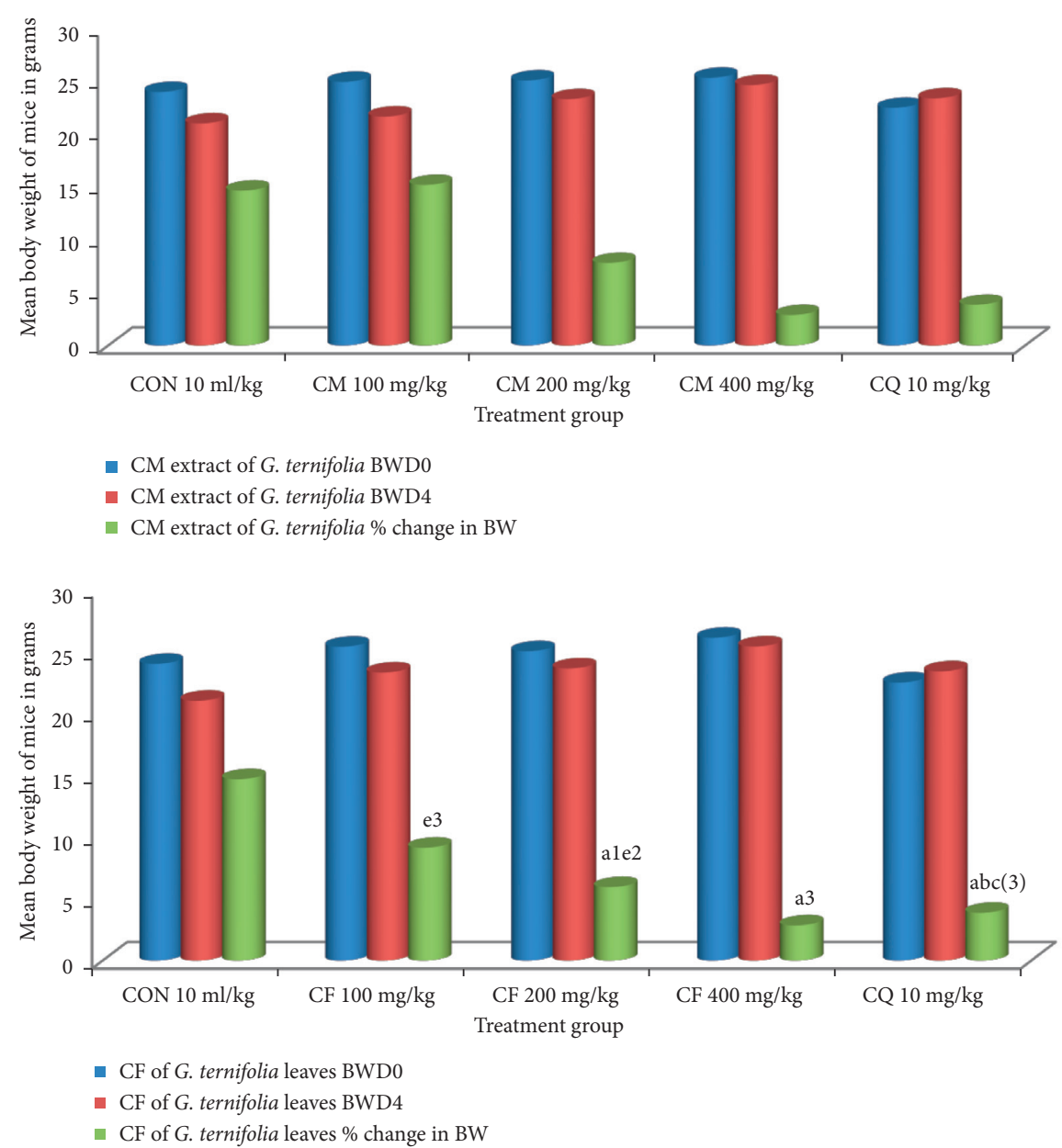

Figure 1: Effect of CM and CF of G. ternifolia on bodyweight of $P$. berghei infected mice in a 4-day suppressive test $(\mathrm{N}=6, \mathrm{CON}=$ negative control (solvent $10 \mathrm{ml} / \mathrm{kg}$ ), BWD0 = bodyweight at day zero, BWD4 = bodyweight at day $4, \mathrm{CM}=$ crude methanolic extract, $\mathrm{CF}=\mathrm{chloroform}$ fraction, $\mathrm{CQ}=$ chloroquine). a, compared to negative control; b, compared to $100 \mathrm{mg} / \mathrm{kg}$; c, compared to $200 \mathrm{mg} / \mathrm{kg}$; d, compared to $400 \mathrm{mg} /$ $\mathrm{kg}$; e, compared to CQ10 mg/kg: $1 P<0.05,2 P<0.01,3 P<0.001$.

chloroform fraction of G. ternifolia leaves were investigated by evaluating the chemosuppression during early infection and curative tests. Then, determination of percent parasitemia inhibition and improved survival days are widely used parameters for evaluating of antiplasmodial activities $[25,26]$. Chloroform fraction at $100 \mathrm{mg} / \mathrm{kg} / \mathrm{day}, 200 \mathrm{mg} / \mathrm{kg} /$ day, and $400 \mathrm{mg} / \mathrm{kg} /$ day showed higher percent parasitemia inhibition than the hydromethanolic crude extract $[25,26]$. In the 4-day chemosuppressive and curative test, hydromethanolic crude extract and chloroform fraction of G. ternifolia leaves produced dose-dependent mean percent parasitemia inhibition and prolonged the survival days in $P$. berghei infected mice, the results recorded at the doses administered. Parasitemia level $P$. berghei infected mice treated with hydromethanolic crude extract and chloroform fraction of G. ternifolia leaves was due to a suppressive effect on the multiplication and erythrocyte infectivity of $P$. berghei parasites in mice. Chloroform fraction demonstrated dosedependent higher activity in blood parasitemia inhibition in $P$. berghei than hydromethanolic crude extract. The relatively higher activity of the chloroform fraction might flow from/to secondary metabolites which can be partitioned during fractionation $[9,14-16]$. The mean survival time may well be a significant parameter to determine the antimalarial activity of plant extract [25]. The hydromethanolic crude extract and chloroform fraction of $G$. ternifolia leaves prolonged the survival time of $P$. berghei infected mice dose dependently. This could be due to the presence of secondary metabolites that prevent the pathologic effect of the parasite in the infected mice $[10,14-16,29]$.

Comparing the mean survival time of chloroform fraction and hydromethanolic crude extract, mice treated with chloroform fraction showed higher mean survival time; this may be due to the feed intake depressing effect of metabolites and interfere with the protein digestion by secondary metabolites that may be absent in chloroform fraction [31]. In comparing the result obtained from this study, the three doses of hydromethanolic crude extract and chloroform fraction of $G$. ternifolia leaves showed significant mean percent parasitemia inhibition compared to the 

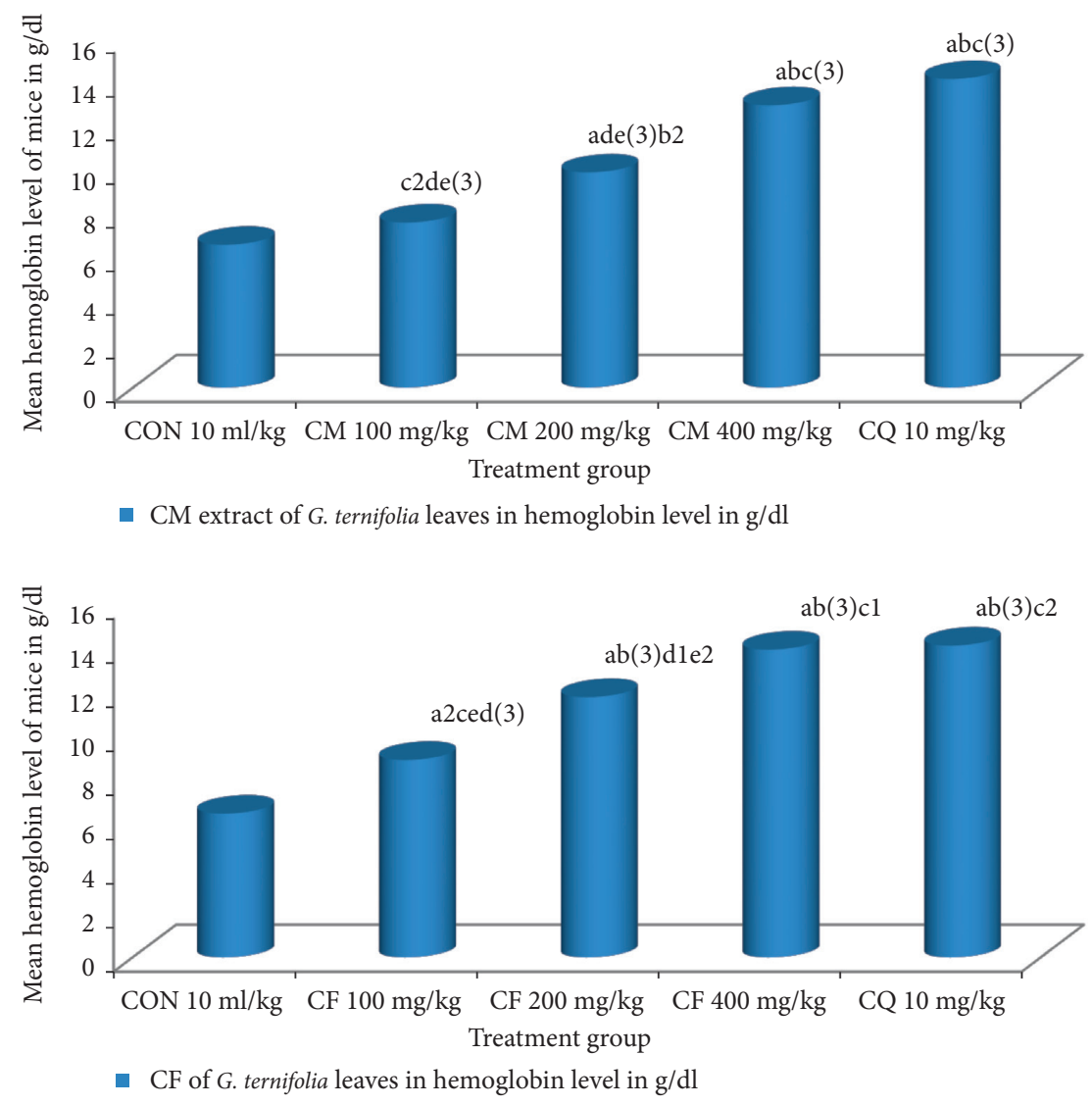

Figure 2: Effect of CM and CF of G. ternifolia on hemoglobin of $P$. berghei infected mice in a 4-day suppressive test $(\mathrm{N}=6, \mathrm{CON}=$ negative control (solvent $10 \mathrm{ml} / \mathrm{kg}$ ), $\mathrm{CM}=$ crude hydromethanolic extract, $\mathrm{CF}=$ chloroform fraction, $\mathrm{CQ}=$ chloroquine). a, compared to negative control; b, compared to $100 \mathrm{mg} / \mathrm{kg}$; c, compared to $200 \mathrm{mg} / \mathrm{kg}$; d, compared to $400 \mathrm{mg} / \mathrm{kg}$; e, compared to CQ10 mg/kg: $1 P<0.05,2 P<0.01$, $3 P<0.001$.

negative control. In vivo antiplasmodial activity is additionally classified as moderate, good, and extremely good if extract displayed percent parasite inhibition is $\geq 50 \%$ at a dose of $500 \mathrm{mg} / \mathrm{kg} / \mathrm{day}, 250 \mathrm{mg} / \mathrm{kg} / \mathrm{day}$, and $100 \mathrm{mg} / \mathrm{kg} /$ day in a 4-day suppressive test, respectively [32]. Supporting this classification, the hydromethanolic crude extract of G. ternifolia leaves at $400 \mathrm{mg} / \mathrm{kg} /$ day showed $67.72 \%$, and chloroform fraction at 400 and $200 \mathrm{mg} / \mathrm{kg} /$ day showed $78.19 \%$ and $63.95 \%$ parasitemia inhibition in P. berghei infected mice, respectively, and exhibited moderate and good antiplasmodial activity. A stronger percentage of parasitemia inhibition was observed in chloroform fraction than the hydromethanolic crude extract at $100 \mathrm{mg} / \mathrm{kg} / \mathrm{day}$, $200 \mathrm{mg} / \mathrm{kg} /$ day, and $400 \mathrm{mg} / \mathrm{kg} /$ day. These results indicated that compounds which have antimalarial activity were soluble in the solvent accustomed extract and fractionate the leaves of G. ternifolia for antimalarial activity. Weight is eminence of plasmodium infection in mice, indicating that a decent antimalarial agent should prevent weight reduction in Plasmodium infected mice. The dose-dependent suppressive activities of hydromethanolic crude extract and chloroform fraction $G$. ternifolia leaves propose that hydromethanolic crude extract and chloroform fraction have not got any toxic effects in experimental mice at the doses evaluated. In the curative test, the mean percent parasitemia was increased in the negative control from the $3^{\text {rd }}$ day to the $5^{\text {th }}$ day. In the Plasmodium berghei infected mice treated with hydromethanolic crude extract and chloroform fraction of $G$. ternifolia leaves, the mean percent parasitemia increased from day 3 to day 4 and showed a decrease in percent parasitemia from the day 5 to day 7 in a dose-dependent manner compared to the negative control. The infected mice treated with chloroquine base showed a decrease in average percent parasitemia from $3^{\text {rd }}$ day to the $7^{\text {th }}$ day.

In the curative test, hydromethanolic crude extract and chloroform fraction of G. ternifolia leaves produced significant difference in percent hemoglobin level compared to the negative control. The hydromethanolic crude extract and chloroform fraction of G. ternifolia leaves at 

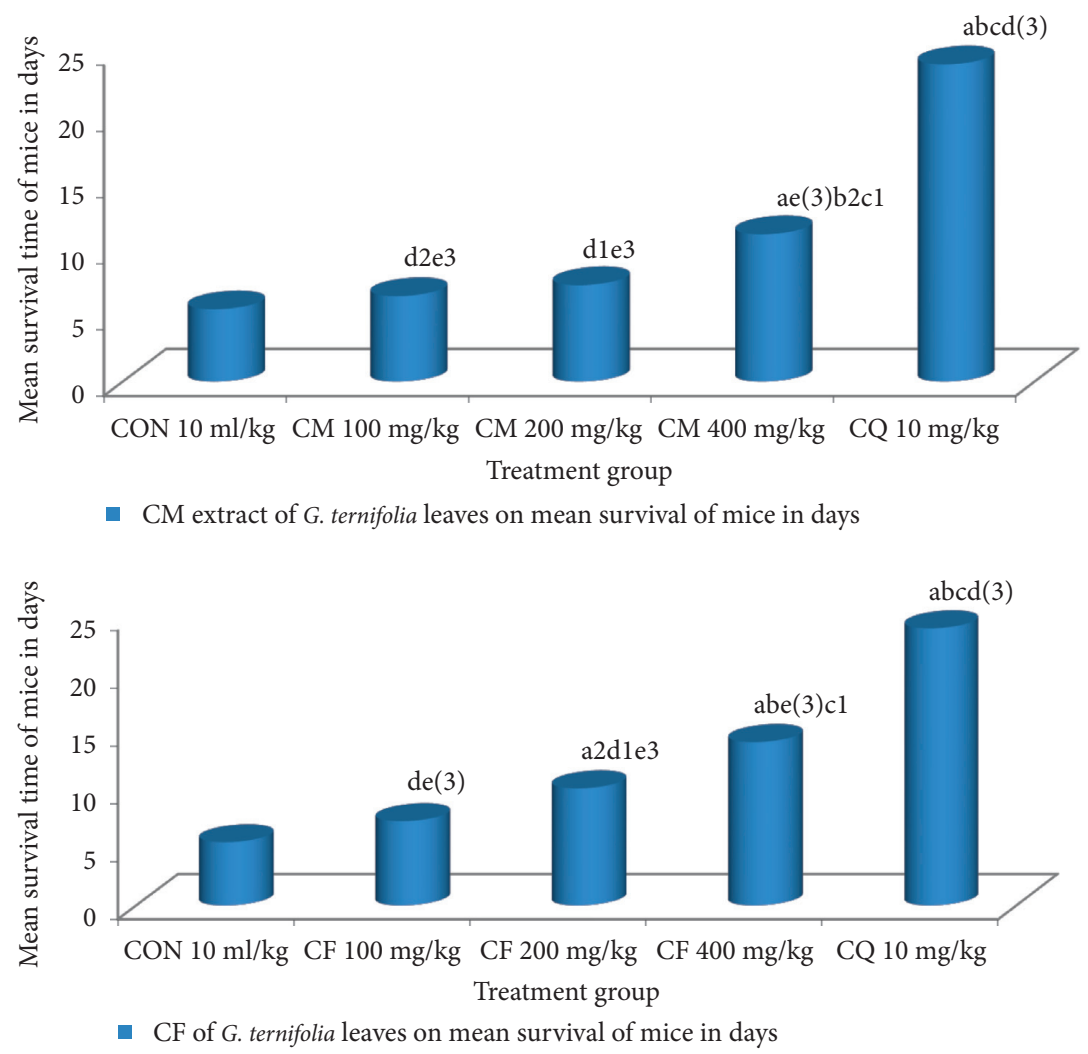

Figure 3: Effect of $\mathrm{CM}$ and $\mathrm{CF}$ of $G$. ternifolia on mean survival time of $P$. berghei infected mice in a 4-day suppressive test $(\mathrm{N}=6$, $\mathrm{CON}=$ negative control (solvent $10 \mathrm{ml} / \mathrm{kg}$ ), $\mathrm{CM}=$ crude methanolic extract, $\mathrm{CF}=$ chloroform fraction, $\mathrm{CQ}=$ chloroquine). a, compared to negative control; b, compared to $100 \mathrm{mg} / \mathrm{kg}$; c, compared to $200 \mathrm{mg} / \mathrm{kg}$; d, compared to $400 \mathrm{mg} / \mathrm{kg}$; e, compared to CQ $10 \mathrm{mg} / \mathrm{kg}$ : $1 P<0.05$, $2 P<0.01,3 P<0.001$.

TABle 3: Mean percent parasitaemia and mean percent parasitemia inhibition of $P$. berghei-infected mice treated with hydromethanolic crude extract and chloroform fraction of G. ternifolia leaves in the Rane's test.

\begin{tabular}{lcccccc}
\hline Extract & $\begin{array}{c}\text { Day } 3 \% \\
\text { parasitemia }\end{array}$ & $\begin{array}{c}\text { Day-4\% } \\
\text { parasitemia }\end{array}$ & \% parasitemia & $\begin{array}{c}\text { Day } 5 \\
\text { para. } \\
\text { inhibition }\end{array}$ & $\begin{array}{c}\text { Day 6 \% } \\
\text { parasitemia }\end{array}$ & $\begin{array}{c}\text { Day } 7 \% \\
\text { parasitemia }\end{array}$ \\
\hline CON $10 \mathrm{ml} / \mathrm{kg}$ & $14.10 \pm 0.54$ & $35.00 \pm 0.56$ & $43.00 \pm 1.58$ & 0 & 0 & 0 \\
$\mathrm{CM} 100 \mathrm{mg} / \mathrm{kg}$ & $15.00 \pm 0.37$ & $34.00 \pm 0.83$ & $32.00 \pm 0.45$ & $25.58 \mathrm{acde}(3)$ & $25.03 \pm 0.59$ & $21.00 \pm 0.48$ \\
$\mathrm{CM} 200 \mathrm{mg} / \mathrm{kg}$ & $14.03 \pm 0.60$ & $27.03 \pm 0.81$ & $27.10 \pm 0.40$ & 36.98 abe (3) & $21.00 \pm 0.46$ & $17.05 \pm 0.34$ \\
$\mathrm{CM} 400 \mathrm{mg} / \mathrm{kg}$ & $15.10 \pm 0.18$ & $26.07 \pm 0.46$ & $22.03 \pm 0.22$ & 48.76 abe (3) & $19.00 \pm 0.60$ & $14.03 \pm 0.23$ \\
$\mathrm{CF} 100 \mathrm{mg} / \mathrm{kg}$ & $12.13 \pm 0.20$ & $29.00 \pm 0.30$ & $23.07 \pm 0.33$ & 46.36 ade (3) c1 & $21.00 \pm 0.37$ & $16.90 \pm 0.23$ \\
CF $200 \mathrm{mg} / \mathrm{kg}$ & $14.05 \pm 0.31$ & $25.00 \pm 0.24$ & $15.97 \pm 0.32$ & 62.87 ade (3) b1 & $11.10 \pm 0.16$ & $10.03 \pm 0.35$ \\
CF $400 \mathrm{mg} / \mathrm{kg}$ & $15.13 \pm 0.53$ & $20.00 \pm 0.52$ & $11.00 \pm 0.47$ & 74.42 abce (3) & $9.00 \pm 0.16$ & $7.17 \pm 0.26$ \\
CQ $10 \mathrm{mg} / \mathrm{kg}$ & $13.10 \pm 0.38$ & $7.07 \pm 0.14$ & $3.07 \pm 0.22$ & 92.87 abcd (3) & $0.00 \pm 0.00$ & $0.00 \pm 0.00$ \\
\hline
\end{tabular}

Data are expressed as mean \pm SEM; $(n=6: C Q=$ chloroquine, $\mathrm{CON}=$ control, $\mathrm{CM}$, crude hydromethanolic extract, $\mathrm{CF}=$ chloroform fraction of Gardenia ternifolia, \% par supp $=\%$ parasitemia suppression). a, compared to negative control; b, compared to $100 \mathrm{mg} / \mathrm{kg}$; c, compared to $200 \mathrm{mg} / \mathrm{kg}$; d, compared to $400 \mathrm{mg} / \mathrm{kg}$; e, compared to CQ10 mg/kg: $1 P<0.05,3 P<0.001$.

doses of 100, 200, and $400 \mathrm{mg} / \mathrm{kg} /$ day showed increased mean survival time with significant difference compared to the negative control and produced highly significant difference $(P<0.001)$ at $400 \mathrm{mg} / \mathrm{kg} /$ day compared to negative control. The promising result from the curative test suggests that the crude extract incorporates a 


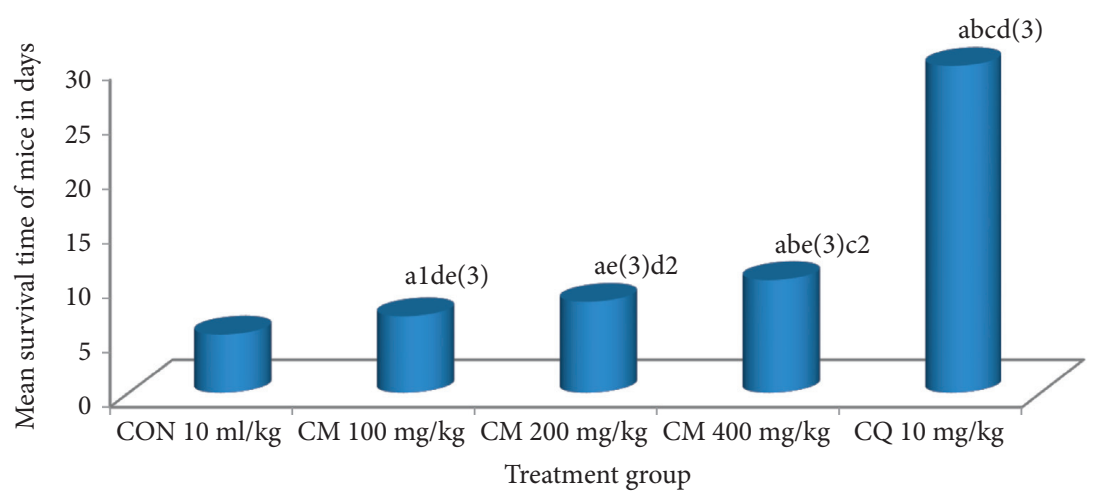

- CM extract of G. ternifolia leaves on mean survival of mice in days

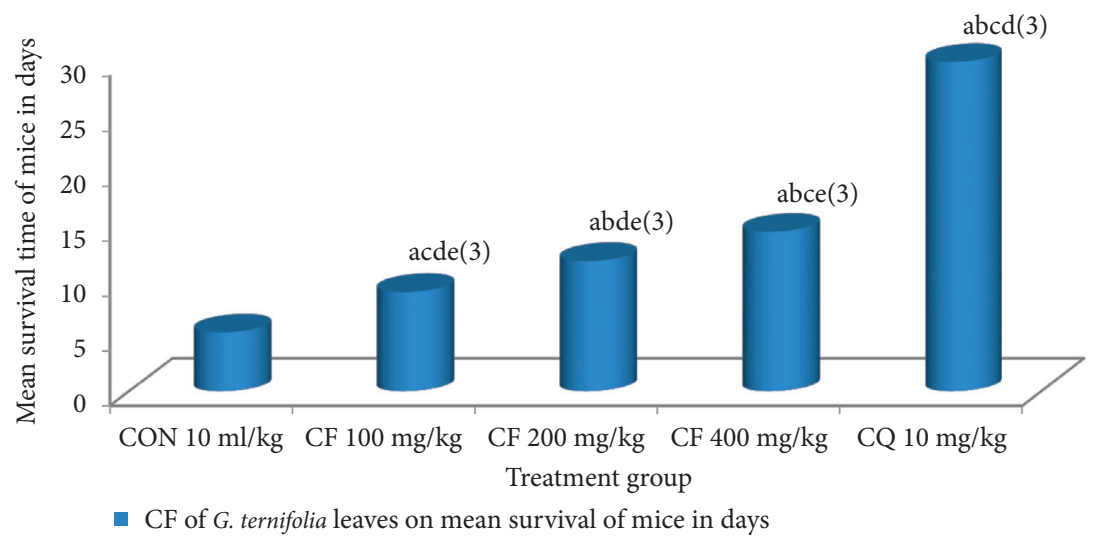

Figure 4: Effect of CM and CF of G. ternifolia on mean survival time of $P$. berghei infected mice in a curative test $(\mathrm{N}=6, \mathrm{CON}=$ negative control (solvent $10 \mathrm{ml} / \mathrm{kg}$ ), $\mathrm{CM}=$ crude methanolic extract, $\mathrm{CF}=$ chloroform fraction, $\mathrm{CQ}=$ chloroquine). a, compared to negative control; b, compared to $100 \mathrm{mg} / \mathrm{kg}$; c, compared to $200 \mathrm{mg} / \mathrm{kg}$; d, compared to $400 \mathrm{mg} / \mathrm{kg}$; e, compared to CQ $10 \mathrm{mg} / \mathrm{kg}: 1 P<0.05,2 P<0.01$, $3 P<0.001$.

therapeutic efficacy against established malarial parasitic infections.

\section{Conclusion}

The hydromethanolic crude extract and chloroform fraction of G. ternifolia leaves have in vivo anti-malarial activities. Chloroform fraction showed relatively better antimalarial effect in all parameters determined than hydromethanolic crude extract of G. ternifolia leaves. The dearth of acute toxicity and antimalarial activity upholds the earlier in vitro findings as well as the folkloric use in Ethiopian traditional medicine. However, species variation would also limit such a straightforward extrapolation of the findings of this study to humans.

7.1. Recommendation. Our study confirmed the claim in Ethiopian traditional medicine that the plant has therapeutic values in malarial infections. So, it needs further in-depth investigation by using primate and other models against $P$. falciparum infection are justifiable. Gardenia ternifolia is multipurpose which is employed for the building of homes, firewood, and animal feed and for treatment of various diseases in both humans and stock that the concerned bodies are advised to require measures to conserve it.

\begin{abstract}
Abbreviations
CQ: Chloroquine

EPHI: Ethiopian Public Health Institute

$\mathrm{IC}_{50}: \quad 50 \%$ inhibitory concentration

$\mathrm{LD}_{50}$ : Median lethal dose 50

PRBCs: Parasitized red blood cells.
\end{abstract}

\section{Data Availability}

All data generated or analyzed during this study have been attached in the supplementary files.

\section{Ethical Approval}

The animals were handled according to the governance of animal care and use for scientific purposes in Africa and the Middle East $[21,22]$. And ethical clearance was requested and obtained from the Institutional Review Board of Debre Tabor University with a permission letter Ref. No. DU/RPD/122/2016 on 09/14/2016 G.C, and the research was done as per the agreement.

\section{Conflicts of Interest}

The authors declare that they have no conflicts of interest. 


\section{Authors' Contributions}

All authors made substantial contributions to conception and design, acquisition of data, or analysis and interpretation of data; took part in drafting the article or revising it critically for important intellectual content; agreed to submit the current journal; gave final approval of the version to be published; and agreed to be accountable for all aspects of the work.

\section{Acknowledgments}

The authors are very grateful to Debre Tabor University for the approval of the ethical clearance and for their technical supports. Then, the authors would like to thank the University of Gondar for support of laboratory facility and authentication of plant material. Lastly, the authors would like to thank Ethiopian Public Health Institute for free delivery of $P$. berghei parasite.

\section{Supplementary Materials}

(1) Raw data: in vivo antimalarial effect of Gardenia ternifolia chemosuppressive data. (2) List of supplies, chemicals, reagents, and equipment used in our research. (Supplementary Materials)

\section{References}

[1] World Health Organization, World Malaria Report 2020: 20 Years of Global Progress and Challenges, World Health Organization, Geneva, Switzerland, 2020.

[2] East African Network for Monitoring Antimalarial Treatment (EANMAT), "The efficacy of antimalarial monotherapies, sulphadoxine-pyrimethamine and amodiaquine in East Africa: implications for sub-regional policy," Tropical Medicine \& International Health, vol. 8, no. 10, pp. 860-867, 2003.

[3] A. O. Talisuna, P. Bloland, and U. D'Alessandro, "History, dynamics, and public health importance of malaria parasite resistance," Clinical Microbiology Reviews, vol. 17, no. 1, pp. 235-254, 2004.

[4] A. Huxley, M. Griffiths, and M. Levy, Dictionary of Gardening: The New Royal Horticultural Society, MacMillan Press, New York, NY, USA, 1992.

[5] H. J. von Maydell, "Trees and Shrubs of the Sahel-their characteristics and Uses," Open Journal of Forestry, vol. 5, no. $4,2015$.

[6] J. O. Kokwaro, Medicinal Plants of East Africa, Published and Printed by Kenya Literature Bureau, Nairobi, Kenya, 1993.

[7] H. Weenen, M. Nkunya, D. Bray, L. Mwasumbi, L. Kinabo, and V. Kilimali, "Antimalarial activity of Tanzanian medicinal plants,” Planta Medica, vol. 56, no. 04, pp. 368-370, 1990.

[8] J. O. Midiwo, J. J. Matasi, O. M. Wanjau, R. W. Mwangi, P. G. Waterman, and E. Wollenweber, "Anti-feedant effects of surface accumulated flavonoids of polygonum senegalense," Bulletin of the Chemical Society of Ethiopia, vol. 4, no. 2, pp. 123-127, 1990.

[9] E. G. Achigan-Dako, S. N'Danikou, F. Assogba-Komlan, B. Ambrose-Oji, A. Ahanchede, and M. W. Pasquini, "Diversity, geographical, and consumption patterns of traditional vegetables in sociolinguistic communities in Benin: implications for domestication and utilization," Economic Botany, vol. 65, no. 2, pp. 129-145, 2011.

[10] C. O. Ochieng, J. Ogweno Mid, and P. Okinda Owu, "Antiplasmodial and larvicidal effects of surface exudates ofGardenia ternifolia aerial parts," Research Journal of Pharmacology, vol. 4, no. 2, pp. 45-50, 2010.

[11] A. H. Al-Adhroey, Z. M. Nor, H. M. Al-Mekhlafi, A. A. Amran, and R. Mahmud, "Antimalarial activity of methanolic leaf extract of Piper betle L," Molecules, vol. 16, no. 1, pp. 107-118, 2011.

[12] D. Nureye, S. Assefa, T. Nedi, and E. Engidawork, "In vivo antimalarial activity of the 80 Methanolic root bark extract and solvent fractions of Gardenia ternifolia Schumach. \& Thonn. (Rubiaceae) against Plasmodium berghei," Evidencebased complementary and alternative medicine, vol. 2018, Article ID 9217835, 10 pages, 2018.

[13] S. F. Zohra, B. Meriem, S. Samira, and M. A. Muneer, "Phytochemical screening and identification of some compounds from mallow," Journal of Natural Product and Plant Resources, vol. 2, no. 4, pp. 512-516, 2012.

[14] F. Alafid, S. M. Edrah, F. M. Meelad, S. Belhaj, K. Altwair, and N. R. Maizah, "Evaluation of phytochemical constituents and antibacterial activity of thymelaea hirsuta (1.) Endl, and that utilised as a conventional treatment of infertility and diabetic in Libya," World Journal of Pharmaceutical Research, vol. 8, no. 11, pp. 72-88, 2019.

[15] A. Scalbert, "Antimicrobial properties of tannins," Phytochemistry, vol. 30, no. 12, pp. 3875-3883, 1991.

[16] H. Usman, F. I. Abdulrahman, and A. Usman, "Qualitative phytochemical screening and in vitro antimicrobial effects of methanol stem bark extract of Ficus thonningii (Moraceae)," African Journal of Traditional, Complementary and Alternative, vol. 6, no. 3, pp. 289-295, 2009.

[17] M. M. Cowan, "Plant products as antimicrobial agents," Clinical Microbiology Reviews, vol. 12, no. 4, pp. 564-582, 1999.

[18] M.-E. Dibua Uju, C. C. Okeke, U. Chioma, K. F. Chimaobi, and O. Austin, "In vivo antimalarial and cytotoxicity activity of ethanolic stem bark of Petersianthus macrocarpus and leaf of Astonia boonei in experimental mice model," International Journal of Current Microbiology and Applied, vol. 2, no. 12, pp. 354-368, 2013.

[19] L. Othman, A. Sleiman, and R. M. Abdel-Massih, "Antimicrobial activity of polyphenols and alkaloids in Middle eastern plants," Frontiers in Microbiology, vol. 10, p. 911, 2019.

[20] C. Omojate Godstime, O. Enwa Felix, O. Jewo Augustina, and O. Eze Christopher, "Mechanisms of antimicrobial actions of phytochemicals against enteric pathogens-a review," Journal of Pharmaceutical, Chemical and Biological Sciences, vol. 2, no. 2, pp. 77-85, 2014.

[21] S. Gollapudi, H. A. Sharma, S. Aggarwal, L. D. Byers, H. E. Ensley, and S. Gupta, "Isolation of a previously unidentified polysaccharide (MAR-10) from Hyssop officinalis that exhibits strong activity against human immunodeficiency virus type 1," Biochemical and Biophysical Research Communications, vol. 210, no. 1, pp. 145-151, 1995.

[22] Organization for Economic Co-operation and Development, Test No. 425: Acute Oral Toxicity: Up-And-Down Procedure, OECD Publishing, Paris, France, 2008.

[23] B. J. Mohr, F. A. Fakoya, J. Hau, O. Souilem, and L. Anestidou, "The governance of animal care and use for scientific purposes in Africa and the Middle East," ILAR Journal, vol. 57, no. 3, pp. 333-346, 2016. 
[24] S. Parasuraman, "Toxicological screening," Journal of Pharmacology and Pharmacotherapeutics, vol. 2, no. 2, pp. 74-79, 2011.

[25] D. A. Fidock, P. J. Rosenthal, S. L. Croft, R. Brun, and S. Nwaka, "Antimalarial drug discovery: efficacy models for compound screening. Supplementary documents," Trends Parasitol, vol. 15, pp. 19-29, 2004.

[26] L. Bantie, S. Assefa, T. Teklehaimanot, and E. Engidawork, "In vivo antimalarial activity of the crude leaf extract and solvent fractions of Croton macrostachyus Hocsht. (Euphorbiaceae) against Plasmodium berghei in mice," BMC Complementary and Alternative Medicine, vol. 14, no. 1, pp. 79-88, 2014.

[27] O. A. Iyiola, A. Y. Tijani, and K. M. Lateef, "Antimalarial activity of ethanolic stem bark extract of Alstonia boonei in mice," Asian Journal of Biological Sciences, vol. 4, no. 3, pp. 235-243, 2011.

[28] A. I. Rappaport, C. D. Karakochuk, K. C. Whitfield, K. M. Kheang, and T. J. Green, "A method comparison study between two hemoglobinometer models (Hemocue $\mathrm{Hb} 301$ and $\mathrm{Hb} \mathrm{201+)} \mathrm{to} \mathrm{measure} \mathrm{hemoglobin} \mathrm{concentrations} \mathrm{and}$ estimate anemia prevalence among women in Preah Vihear, Cambodia," International Journal of Laboratory Hematology, vol. 39, no. 1, pp. 95-100, 2017.

[29] T. Ozcan, A. Akpinar-Bayizit, L. Yilmaz-Ersan, and B. Delikanli, "Phenolics in human health," International Journal of Chemical Engineering and Applications, vol. 5, no. 5, p. 393, 2014.

[30] P. C. Gurney, S. S. Elliott, E. Vom, S. J. Spence, S. Bagnato, and A. Watkins, "Inventors; leica biosystems melbourne pty ltd, assignee. Method and apparatus for tissue sample processing," United States Patent Application US, vol. 11/867, p. 760, 2008.

[31] J. F. Ryley and W. Peters, "The antimalarial activity of some quinolone esters," Annals of Tropical Medicine \& Parasitology, vol. 64, no. 2, pp. 209-222, 1970.

[32] W. Deressa, D. Olana, and S. Chibsa, "Magnitude of malaria admissions and deaths at hospitals and health centers in Oromia, Ethiopia," Ethiopian Medical Journal, vol. 42, no. 4, pp. 237-246, 2004. 